\title{
A FISCALIZAÇÃO TRIBUTÁRIA E SEUS LIMITES: UMA ANÁLISE A PARTIR DO PRINCÍPIO DA LEGALIDADE E DOS DIREITOS FUNDAMENTAIS DO CONTRIBUINTE
} THE TAX INSPECTION AND ITS LIMITS: AN ANALYSIS FROM THE PRINCIPLE OF LEGALITY AND OF FUNDAMENTAL RIGTHS OF THE

\section{TAXPAYER}

\author{
1 Tiago Cappi Janini \\ ${ }^{2}$ Ana Luiza Godoy Pulcinelli
}

\section{Resumo}

Este estudo pretende demonstrar a necessidade de imposição de limites à fiscalização tributária, para que seja legal, justa e adequada. Nesse sentido, objetiva-se identificar a importância do princípio da legalidade para a fiscalização tributária. Utilizando-se o método dedutivo, a partir de pesquisa bibliográfica, legislativa e jurisprudencial se observou que a Administração Tributária tem seu agir pautado na lei, sendo também o seu limite, o qual é dúplice, pois a Administração Tributária, mesmo possuindo privilégios no cumprimento de seu mister, deve respeitar, além da legislação tributária propriamente dita, os direitos fundamentais individuais dos fiscalizados.

Palavras-Chave: Direito Tributário. Princípio da legalidade. Fiscalização Tributária. Direitos fundamentais do contribuinte.

\begin{abstract}
This study aims to demonstrate the need to impose limits on tax inspection, that is legal, fair and adequate. In this sense, the objective is to identify the importance of the principle of legality to the tax inspection. Using the deductive method, from literature, legislative and jurisprudential research is noted that the Tax Administration has its act guided by the law and is also its limit, which is twofold, since the Tax Administration even having privileges in compliance of his profession must, in addition to the tax law itself, individual fundamental rights overseen.
\end{abstract}

Keywords: Tax Law. Principle of legality. Tax Inspection. Fundamental Rights of the taxpayer.

\footnotetext{
${ }^{1}$ Professor na Universidade Estadual do Norte do Paraná, UENP- PR, (Brasil). Doutor e mestre em Direito do Estado pela Pontifícia Universidade Catolica de São Paulo,PUC - SP, (Brasil). E-mail: tiagocappi@yahoo.com.br.

${ }^{2}$ Mestranda em Ciência Jurídica pelo Programa de Pós-Graduação em Ciência Jurídica da Universidade Estadual do Norte do Paraná, UENP- PR, (Brasil). Professora de Direito Tributário na Universidade Estadual do Norte do Paraná, UENP- PR, (Brasil), campus Cornélio Procópio. E-mail: luizapulcinelli@uenp.edu.br.
} 


\section{INTRODUÇÃO}

O Poder Público necessita de recursos financeiros para manter sua estrutura organizacional e desenvolver políticas públicas. Grande parte desses investimentos decorre dos tributos arrecadados pelo Estado. Nesse cenário, ganha importância a Administração Tributária que busca arrecadar dinheiro com o intuito de satisfazer as necessidades do Poder Público. Até chegar a essa fase final, há um longo caminho jurídico a ser percorrido, desde o exercício das competências tributárias constitucionalmente previstas até o efetivo pagamento do tributo pelo contribuinte. Sucede que tal percurso é sobremodo complexo, exigindo atos do Poder Legislativo, do Poder Executivo, do Poder Judicial e do próprio particular. Nesse trajeto inclui-se a fiscalização tributária que, em suma, tem por finalidade averiguar se o contribuinte realizou corretamente as obrigações que lhe são impostas.

Com a finalidade de concretizar esse ato de fiscalização, a legislação tributária outorga às autoridades fiscais algumas prerrogativas eficazes no combate à sonegação fiscal. Todavia, o Estado, no escopo de efetivar a cobrança dos tributos, não se pode valer de práticas autoritárias e arbitrárias. Por isso, o sistema jurídico impõe limites à atividade fiscalizatória.

Nesse sentido, este estudo objetiva analisar a importância do princípio da legalidade como um verdadeiro limite para o exercício da atividade fiscalizatória pela Administração Tributária. Por outro lado, a legalidade é igualmente responsável por apontar os privilégios que a atividade administrativa possui. Desse modo, demonstrar-se-á a importância do princípio da legalidade para a fiscalização tributária. Ademais, aparece outra questão: basta a Administração Tributária seguir aquilo que a lei determina? Há outros limites que balizam a fiscalização tributária, tais como os direitos fundamentais?

Utilizando-se o método dedutivo a partir de pesquisa bibliográfica, legislativa e jurisprudencial, pretende-se demonstrar a importância do princípio da legalidade administrativa e dos direitos fundamentais do contribuinte para fins de uma fiscalização tributária legal, justa e adequada. 


\section{A FISCALIZAÇÃO TRIBUTÁRIA}

A Administração Tributária é estruturada por leis especiais de organização administrativa tributária, direcionando as atividades do Estado para a arrecadação dos tributos: administração, lançamento, fiscalização e julgamento administrativo (NOGUEIRA, 1995, p. 219-220). O CTN trata da Administração Tributária no Título IV (artigos 194 a 208), tendo como pilares a fiscalização, a dívida ativa e as certidões.

Nesse contexto, a fiscalização é um mecanismo de controle, em que o Poder Público irá observar o contribuinte com a finalidade de verificar se seu comportamento está conforme os ditames da legislação tributária. É umas das atividades do Estado para fins de arrecadação tributária, ao lado da cobrança dos inadimplentes e do controle da quitação dos débitos tributários por meio da emissão de certidões negativas.

A palavra "fiscalização" é mais uma daquelas que sofre da ambiguidade processo/produto. Esse tipo de problema aparece no uso de uma mesma palavra que representa um processo, uma atividade, e que designa o produto, o resultado desse processo. Essa ambiguidade é observada na seguinte oração: "foram ver a construção", que pode significar que foram ver (i) as pessoas atuando no processo de construir algo, ou (ii) a coisa já construída (HOSPERS, 1984, p. 29). Desse modo, "fiscalização tributária" pode significar tanto a ação fiscalizatória realizada pela Administração Tributária, quanto o seu resultado: a constituição de um novo crédito tributário, a imposição de multa, etc ${ }^{3}$.

A atividade fiscalizatória consiste na averiguação, no exame, na vigilância que o agente público exerce sobre o particular com a finalidade de identificar se as obrigações tributárias foram devidamente cumpridas nos termos da lei. São, portanto, objeto desse processo investigativo a obrigação principal, que decorre do fato jurídico tributário e estipula um valor a ser pago pelo contribuinte a título de tributo; e a obrigação acessória, que imputa ao particular prestações, positivas ou negativas, destinas à arrecadação ou à fiscalização dos tributos.

\footnotetext{
${ }^{3}$ Importa mencionar que os significados da palavra "fiscalização" reduzem-se a apenas a atividade fiscalizatória ou ao seu produto. "Fiscalização", para demonstrar seu multiuso, pode também ser usada em um sentido subjetivo, indicando a pessoa ou a instituição que fiscaliza.
} 
Em síntese, a atividade de fiscalização consiste em (i) (re)construir o fato jurídico tributário, tanto nos casos de constituição do crédito tributário pela autoridade administrativa por meio do lançamento (art. 142 do CTN), quanto na hipótese em que o contribuinte deveria formalizar o crédito tributário pelo autolançamento (art. 150 do CTN) e não o fez, ou (ii) verificar se as informações apresentadas pelo contribuinte nas obrigações acessórias são verdadeiras.

Esse agir da Administração Tributária fica representado no seu produto: um documento, o "Auto de Infração" por exemplo, que irá conter o resultado do processo fiscalizatório, indicando se o contribuinte cumpriu ou não as diretrizes legais, e quais são as suas consequências jurídicas.

\section{A FISCALIZAÇÃO TRIBUTÁRIA COMO ATIVIDADE ADMINISTRATIVA}

Parece não haver dúvidas de que a atividade de fiscalização tributária caracteriza-se como um ato da Administração Pública, sujeitando-se, portanto, ao regime jurídico administrativo $^{4}$, ou seja, ao conjunto de regras e princípios que outorgam identidade ao direito administrativo em face do direito privado, caracterizado pelo binômio prerrogativas/restrições. Atualmente, é importante consignar, que os princípios ganham papel de relevo na normatização das relações jurídicas, especialmente as de direito público.

O direito administrativo fundamenta-se na liberdade do indivíduo, em razão dos direitos fundamentais consagrados na Constituição Federal, e na autoridade da Administração Pública necessária para concretizar os interesses coletivos. Por essa razão, Maria Sylvia Di Pietro (2015, p. 95 - grifo do original) afirma que essa disciplina nasce e se desenvolve baseada em duas ideias opostas:

\footnotetext{
${ }^{4}$ Conforme Maria Sylvia di Pietro (2015, p. 94), a expressão "regime jurídico administrativo" possui um sentido amplo, que designa os regimes de direito público e de direito privado a que pode se submeter a Administração Pública, e outro sentido estrito utilizada para o conjunto de traços, de conotações, que tipificam o Direito Administrativo, inserindo o Poder Público em uma posição privilegiada na relação jurídica-administrativa. Neste estudo, como se observa, utilizar-se-á a expressão em seu sentido estrito.
} 
[...] de um lado, a proteção aos direitos individuais frente ao Estado, que serve de fundamento ao princípio da legalidade, um dos esteios do Estado de Direito; de outro lado, a de necessidade de satisfação dos interesses coletivos, que conduz à outorga de prerrogativas e privilégios para a Administração Pública, quer para limitar o exercício dos direitos individuais em benefício do bem-estar coletivo (poder de polícia), quer para a prestação de serviços públicos.

Desse modo, ao exercer a atividade administrativa, o Poder Público possui limites que o impedem de infringir os direitos individuais e, por outro lado, tem prerrogativas e privilégios que lhe permite buscar o interesse público, colocando a Administração Pública em uma posição de supremacia perante o particular.

Assim, quando o Poder Público age na consecução dos seus fins, o sistema jurídico administrativo lhe outorga alguns privilégios, desconhecidos do âmbito privado, com o escopo de atingir o bem estar coletivo. É o caso do poder de expropriação, de ocupar temporariamente imóvel alheio, de alterar e rescindir unilateralmente as regras contratuais, entre outros.

Em contrapartida, essas prerrogativas não podem ser ilimitadas, garantindo um poder divino ao administrador. Elas necessariamente têm de se adaptar aos direitos fundamentais dos indivíduos. Por isso, o art. 37, caput da Constituição Federal exige que a Administração Pública obedeça aos princípios da legalidade, da impessoalidade, da moralidade, da publicidade e da eficiência.

A fiscalização tributária, vista como uma atividade administrativa, submete-se ao regime jurídico administrativo. É o que também pensa Ruy Barbosa Nogueira (1995, p. 244, grifo do original): "O poder de fiscalizar decorre do Poder Administrativo e por isso o seu exercício é feito por meio de procedimentos jurídicos semelhantes aos do Direito Administrativo, o que significa por atos privilegiados: ato de ofício e executórios quando concluídos".

Para realizar o procedimento físcalizatório, o ordenamento jurídico concede à Administração Tributária algumas prerrogativas que a autoriza ingressar na esfera privada dos cidadãos, com o escopo de verificar se foram devidamente cumpridas as obrigações a eles impostas. Assim, a legislação autoriza o Poder Público realizar diligências, apreender mercadorias e documentos, interditar estabelecimentos, etc. 
Todavia, essa atuação do Estado está sujeita a limites que evitem o desrespeito de direitos fundamentais do contribuinte. É, inclusive, o que prescreve o $\S 1^{\circ}$ do art. 145 da Constituição Federal, ao permitir à Administração Tributária, identificar o patrimônio, os rendimentos e as atividades econômicas do contribuinte, desde que respeitados os direitos individuais e que se aja nos termos da lei.

Com isso, constata-se que a fiscalização tributária deve ser exercida observando-se os direitos fundamentais, mas também esses direitos fundamentais do contribuinte não devem ser usados como escudo para obstar a atividade fiscalizatória. São mecanismos de defesa contra uma tributação arbitrária e abusiva.

Nesse cenário, importa destacar o princípio da legalidade, princípio basilar do regime jurídico-administrativo, que impõe ao Estado o dever de submissão à lei, preservando, com isso, os direitos individuais dos cidadãos.

\section{ASPECTOS DO PRINCÍPIO DA LEGALIDADE}

Muito embora o princípio da legalidade esteja vinculado ao Estado de Direito, sua origem é mais remota, desenvolvendo-se como forma de combater a tributação tirânica, imposta pelo Soberano aos seus súditos, ligado à ideia de que os impostos só poderiam ser criados pelas assembleias representativas, conectado à autotributação (XAVIER, 1978, p. 07).

O princípio da legalidade vinculado à criação de impostos começa a aparecer no início do século XI, especialmente na Inglaterra, com o surgimento de diversos registros da exigência de consentimento - inicialmente individual e, posteriormente, coletivo - dos contribuintes para a instituição e arrecadação de tributos ${ }^{5}$. Sérgio Assoni Filho descreve essas primeiras manifestações da legalidade (2003, p. 183):

Na Inglaterra, surgiram várias manifestações de cunho consuetudinário nesse sentido, como por exemplo, a promessa de recompensa a William Rufus pela conquista da Normandia, que teve em 1096, o seu valor aumentado somente após o consentimento do Bispado.

Surge, em 1179, a proibição do Bispado de taxar o clero sem o prévio consentimento dos arquidiáconos, por meio do chamado Lateran Council.

\footnotetext{
${ }^{5}$ Acerca disso diz Victor Uckmar que "Geralmente imputa-se à Magna Charta a primeira afirmação do princípio de que nenhuma prestação pecuniária pode ser imposta, se não por deliberação dos órgãos legislativos. Porém, a origem se encontra em época anterior: por exemplo, na Inglaterra, o Rei, que já percebia impostos e obtinha subsídios pelo direito consuetudinário, exigia dos vassalos, para fazer frente a despesas extraordinárias, pagamentos em dinheiro e estes podiam - embora fosse praticamente impossível - impugná-los".
} 
No mesmo sentido, em 1188, corpos colegiais compostos por membros do alto clero e da nobreza autorizaram o Rei Henrique II a instituir um tributo de dez por cento sobre a renda, para que tais recursos fossem empregados nas despesas com as Cruzadas contra Saladino. Em 1192, Henrique IV convoca reuniões e assembléias para deliberar sobre o pagamento do resgate de Ricardo I, que era mantido prisioneiro do Duque da Áustria.

Em 1197, nobreza e alto clero realizaram uma assembleia para deliberar sobre o dever de pagar uma soma em dinheiro em substituição à prestação do serviço militar requerido pelo Rei.

Já em 1207, para a reconquista de terras perdidas para a França, a Magna Curia Regis deliberou no sentido de arrecadar a importância de um treze avos das rendas dos proprietários das terras inglesas.

Insta salientar que eram tempos de centralização do poder na esfera social e religiosa na Europa Ocidental. Com o feudalismo chegando ao seu fim, "foi-se afirmando, rapidamente, a predominância de um dos suseranos sobre os outros, ou seja, teve início o movimento gerador de um primus inter pares, que viria a ser o Rei” (COMPARATO, 2013, p.84). A exação fiscal sem limites realizada pelo Rei gerava a revolta dos barões que exigiam a imposição de um limite a essas cobranças, com a possibilidade de controle pelo consentimento, concretizado por meio de seus representantes.

Após esse período de revoltas, o princípio da legalidade fortalece-se com a promulgação da Magna Carta pelo Rei João Sem Terra em 1215, fruto da marcha dos barões ingleses até Londres e das ameaças por eles impostas ao Rei, que se viu obrigado a assinar o documento sob pena de perder o apoio dos barões, o que tornaria seu reinado impraticável. “Desse modo, formalmente, o Rei não mais poderia impor obrigações de cunho tributário apenas com base em sua autoridade ou arbítrio, pois tais obrigações somente seriam legítimas se o necessário consentimento popular se manifestasse." (ASSONI. 2003,183). Além disso, é importante ressaltar que, “[...] com este documento, pela primeira vez na história medieval se deixa implícito que o rei naturalmente vincula-se às próprias leis que edita” (BESTER, 2005, 40).

Até aquele momento o Rei não encontrava limites à sua vontade, governava absoluto, financiando suas atividades bélicas e conquista de territórios com impostos obtidos do povo, mantendo a nobreza e o clero isentos da maioria dos impostos, o que gerou miséria e revolta fora dos limites do castelo. "Aquilo que, entretanto, interessa é que o Rei, ao invés de impor, 
por ato de autoridade, prestações financeiras, devia obter o prévio consentimento dos representantes da nação.” (UCKMAR, 1976, p. 13-14).

Com a evolução do Estado para um Estado de Direito, cujas características básicas eram a divisão de poderes, a garantia dos direitos individuais e, especialmente, a submissão do Estado ao império da lei (SILVA, 1998, p. 116), o princípio da legalidade ganha destaque, indo além das relações tributárias e penais.

Estado de Direito é "[...] aquele que tem a justiça por fim e a lei como meio de sua realização" (XAVIER, 1978, p. 08) e a contribuição da legalidade tributária para o surgimento desta forma de Estado está no fato de:

[...] por um lado, o princípio de que os impostos só podem ser criados por lei formal, o que, no rigor de uma estrita separação de poderes, se traduziria na ideia de que a criação dos tributos é da exclusiva competência das assembléias legislativas; por outro lado, o princípio de que as intervenções do poder na esfera da liberdade e de propriedade dos cidadãos carecem de lei que as autorize, o que é a essência mesma do conceito de reserva de lei.

Pode, porém, afirmar-se ter sido no terreno da tributação que o Estado de Direito foi buscar os principais instrumentos técnicos em que assenta: a própria separação de poderes e o conceito de reserva de lei (XAVIER, 1978, p. 07-08).

A partir de então há a preocupação em se evitar poderes absolutos que tolham os direitos dos indivíduos, colocando a lei como limite para a atuação do Poder Público. O princípio da legalidade se consubstancia como um verdadeiro direito de não intervenção do Estado nas liberdades do cidadão, senão por meio de lei, a ponto de Gilmar Mendes e Paulo Gustavo Gonet Branco afirmarem que "O princípio da legalidade, assim, opõe-se a qualquer tipo de poder autoritário e a toda tendência de exacerbação individualista e personalista dos governantes" (2014, p.768).

É como se expressa Celso Antônio Bandeira de Mello (2014, p. 103):

O princípio da legalidade contrapõe-se, portanto, e visceralmente, a quaisquer tendências de exacerbação personalista dos governantes. Opõe-se a todas as formas de poder autoritário, desde o absolutista, contra o qual irrompeu, até as manifestações caudilhescas ou messiânicas típicas dos países subdesenvolvidos. $\mathrm{O}$ princípio da legalidade é o antídoto natural do poder monocrático ou oligárquico, pois tem como raiz a ideia de soberania popular, de exaltação da cidadania.

Desse modo, com a ideia contemporânea de Estado de Direito, em que governantes e governados sujeitam-se ao império da lei, o princípio da legalidade torna-se fundamental para pautar não só as condutas da Administração Pública, mas também as dos particulares. Nesse interregno a nossa Constituição emoldura-o trazendo à luz não só forma ao Estado, como também sua razão de ser, estampando os objetivos a quevisavam e os meios garantidores de 
sua satisfação, delineando, dessa forma, a importância da legalidade tributária como garantia fundamental aos limites do poder de tributar do Estado.

Dito isso, é possível encontrar, pelo menos, três prismas distintos do princípio da legalidade na Constituição da República Federativa do Brasil de 1988, cujas vertentes remetem a uma mesma palavra: limite. No art. $5^{\circ}$, inciso II, está previsto um dos cânones do Estado Democrático de Direito, determinando que ninguém é obrigado a fazer ou deixar de fazer alguma coisa senão em virtude de lei. O inciso I do art. 150 explicita o princípio da legalidade tributária que proíbe a instituição e o aumento de tributos sem lei que o estabeleça. E o art. 37, caput, impõe à Administração Pública obediência ao princípio da legalidade.

Antes de ingressar especificamente em cada aspecto do princípio da legalidade, importa destacar, brevemente, o significado da palavra "lei".

\subsection{O QUE É “LEI” PARA O PRINCÍPIO DA LEGALIDADE}

Apesar de não suscitar muitas dúvidas, entende-se oportuno esclarecer o que significa "lei" quando se trata do princípio da legalidade. Ao se considerar o princípio da legalidade como um dos pilares do Estado Democrático de Direito, só se poderia entender o vocábulo "lei" como significando ato emanado do Poder Legislativo, produzido de acordo com o procedimento estabelecido na Constituição Federal, pois "[...] é no procedimento legislativo, nos atos de produção legislativa que, indiscutivelmente, se surpreende a realização por excelência tanto da representatividade republicana quanto da participação popular democrática” (VIEIRA, 2004, p. 182).

Bem que se diga que o art. 84, IV, da Constituição Federal exige que até os mais eminentes atos administrativos, decretos e regulamentos presidenciais se submetam à fiel execução da lei. Lei aqui não pode ser entendida como ato da administração pública (vinculado ou discricionário) e sim como lei "em seu sentido formal, como a norma produzida pelo órgão competente (parlamento) e segundo o processo legislativo previstos na Constituição" (MENDES; BRANCO, 2014, p. 770). 
Assim, ficam fora do conceito de lei atos emanados por outros poderes, obviamente em suas funções típicas, que não o legislativo. Deve-se restringir ainda mais os atos classificados como lei, excluindo os atos executivos e judiciais que o Poder Legislativo, em determinadas situações, está autorizado a elaborar.

\subsection{O ASPECTO PRIVADO DO PRINCÍPIO DA LEGALIDADE}

O primeiro aspecto a destacar do princípio da legalidade, embora de forma breve, consiste na sua importância para as relações entre os particulares. Sua origem remonta à Revolução Francesa e seu fundamento está na primeira base sobre a qual se fundou a revolução: a liberdade. Os burgueses reivindicavam o exercício da liberdade mercantil principalmente, mas que refletiu também no exercício da liberdade pessoal, que, então, passa a ter seu exercício garantido por lei. Mesmo com o decorrer dos séculos e a transição do Estado Liberal em Estado Social, a lei ainda é o meio de garantir o exercício das liberdades, assegurando aos particulares a sujeição apenas à vontade da lei.

No Brasil, ninguém está obrigado a fazer ou deixar de fazer algo senão em virtude de lei. Assim dispõe o art. 5º II, da Constituição Federal de 1988, que reitera o contido nas Constituições anteriores. "Daí, no Direito privado, o princípio da legalidade importa na possibilidade de fazer o que a Lei não proíbe (art. $5^{\circ}$, II, da CF), ao passo que o administrador público só pode fazer o que a Lei o autoriza.” (BRITO; RUIZ, 2003).

Em regra, o particular é livre em suas condutas, que são direcionadas exclusivamente por meio de lei. Essa liberdade, todavia, só encontra óbice na lei. É o que se encontra nas lições de Roque Carrazza:

A vida social não é possível sem certas restrições à atividade individual. Estas restrições, porém, unicamente podem ser estabelecidas pela lei, que deve ter um caráter geral e igualitário. Sobremais, deve ser elaborada por mandatários do povo, obedecidos o processo legislativo que a Constituição traça e o próprio princípio republicano (2006, p. 210).

Dirley da Cunha Junior confirma que "[...] a extensão dessa liberdade depende do que se deve entender por lei, já que é ela o único instrumento autorizado pela Constituição para restringir a ação das pessoas.” (2008, p. 648). Em suma, a liberdade dos particulares só pode ser condicionada por uma lei, que tem de seguir expressamente o disposto na Constituição Federal no que diz respeito à sua produção e ao seu conteúdo. 


\subsection{A LEGALIDADE TRIBUTÁRIA}

A vertente do princípio da legalidade no âmbito tributário está estampada no art. 150, I da Constituição Federal que proíbe a União, os Estados, o Distrito Federal e os Municípios instituírem ou aumentarem tributos sem lei. É, portanto, legislando que se cria um tributo. $\mathrm{O}$ princípio da legalidade no Direito Tributário indica que “[...] a instituição dos tributos e, portanto a formação dos tipos tributários, nos seus contornos essenciais, é monopólio das normas revestidas de força de lei, dimanadas dos órgãos legislativos competentes, por antonomásia as Assembleias representativas” (XAVIER, 1978, p. 71).

Um dos aspectos mais relevantes do princípio da legalidade dos tributos é a previsão em lei do "fato gerador". Só há fato jurídico tributário quando se tem sua descrição em lei. Sem definição legal, sem fato.

Sem essa previsão ou definição em lei, não se configurará o fato gerador. Haverá um fato da vida comum, ou um fato econômico, ou mesmo um fato relevante para outros ramos do Direito: para o Direito Tributário, será ele um fato juridicamente irrelevante, no que diz respeito ao nascimento da obrigação tributária (FALCÃO, 2013, p. 18).

Não só o fato jurídico tributário tem de estar contido na lei. Os demais elementos que constituem a obrigação tributária requerem previsão legal. Para se identificar o fato jurídico tributário, bem como a relação jurídica tributária com os seus sujeitos ativo e passivo, a base de cálculo e a alíquota do tributo é necessária a elaboração de uma lei, seguindo rigorosamente a norma de competência prevista constitucionalmente. "Enquanto a criação consiste no definir em lei os aspectos da hipótese de incidência, em estabelecer o critério de mensuração (base de cálculo) e definir a alíquota, a majoração implica alterar o critério legal de base de cálculo, de molde a tornar o tributo mais oneroso" (BARRETO, 1998, p. 147).

Desse modo, salvo raras exceções, a criação e o aumento de tributos só pode ocorrer por meio de lei. É exigência constitucional.

\subsection{A LEGALIDADE ADMINISTRATIVA}


O princípio da legalidade é um dos principais pilares de sustentação do regime jurídico administrativo, tendo em vista que o Direito Administrativo decorre do Estado de Direito; nasce com a submissão do Estado à lei (MELLO, 2014, p. 103). O conceito de legalidade, tal como estampado no caput do art. 37 da Constituição Federal, está ligado ao fato de que a Administração Pública pode fazer apenas o que a lei determinar, enquanto que ao particular está permitido tudo o que a lei não veda, em decorrência do princípio da autonomia da vontade.

A Administração Pública, em toda sua atividade, deve agir no estrito cumprimento da lei, limitando e restringindo direitos dos administrados na forma nela descrita, sendo que mesmo o ato discricionário "[...] aquele em que há margem de liberdade para escolha de consequências (válidas prima facie), segundo espaço decisório conferido por lei e nos limites do sistema" (FREITAS, 2009, p. 361) tem como limite final a observância dos princípios da Administração Pública, especialmente o da legalidade. O agir administrativo, portanto, pautase por aquilo que a lei determina, restando pouca ou nenhuma margem de escolha para o administrador.

Não compete à Administração Pública, nem mesmo no exercício do seu Poder Normativo, criar novas obrigações aos particulares. Cabe-lhe aplicar a lei, como bem explica Celso Antônio Bandeira de Mello: “[...] a função do ato administrativo só poderá ser a de agregar à lei nível de concreção; nunca lhe assistirá instaurar originariamente qualquer cerceio a direitos de terceiros" (2014, p. 106).

Tais diretrizes são aplicáveis à Administração Tributária no exercício da atividade fiscalizatória. Ao investigar as condutas dos contribuintes, o Fisco tem de seguir fielmente o disposto pela lei e pela Constituição. Não pode agir arbitrariamente, exigir mais do que a lei recomenda. A atividade fiscalizatória não é ilimitada. É regulada pela lei e pelos direitos fundamentais do contribuinte.

\section{O PRINCÍPIO DA LEGALIDADE ADMINISTRATIVA E OS DIREITOS FUNDAMENTAIS DO CONTRIBUINTE COMO LIMITES PARA A FISCALIZAÇÃO TRIBUTÁRIA}


Como dito acima, a atividade de fiscalização tributária tem como escopo (re)construir o fato jurídico tributário ou observar se as obrigações acessórias apresentadas pelo contribuinte estão de acordo com a legislação tributária. Também, procurou-se demonstrar que esse poder de investigação das autoridades fiscais, apesar de ser contemplado por diversas prerrogativas pela lei, não é ilimitado.

Um dos principais pilares do regime-jurídico administrativo é o princípio da legalidade, que tem como finalidade obrigar o administrador a seguir rigorosamente aquilo que a lei determina. A atividade fiscalizatória só pode ser exercida na conformidade da lei. Dito de outra forma: o agente fiscalizador só pode exercer atos investigativos do patrimônio do particular quando previstos legalmente. Agir de modo diverso consuma ato administrativo arbitrário; ilícito perante nosso sistema jurídico.

A atividade administrativa de fiscalização pautada na lei possibilita uma investigação criteriosa, que respeita o contribuinte, permitindo-lhe a ampla defesa e contraditório e assegurando-lhe uma tributação justa. $\mathrm{Na}$ Apelação em Mandado de Segurança $\mathrm{n}^{\circ}$ 200139000107353, julgada pela $5^{\text {a }}$ Turma Suplementar do TRF1 em 24/09/2013 ${ }^{6}$ observa-se que a Lei $n^{\circ} 4.502 / 64$ previu expressamente a pena de perdimento e apreensão de mercadoria. Ao assim agir, a Administração Tributária cumpre o seu estrito dever legal. Esse caso, especificamente, tinha como finalidade liberar as mercadorias apreendidas (relógios), tendo em vista a ausência de selo de controle do IPI. A Lei $n^{\circ} 4.502 / 64$, art. 46, autoriza o uso de selos para controle quantitativo da mercadoria para fins de incidência do IPI sobre determinados produtos importados ou industrializados. Aduz, em seu $\S 2^{\circ}$ que a ausência do

6 TRIBUTÁRIO. MANDADO DE SEGURANÇA. APREENSÃO DE MERCADORIA. PRODUTOS NÃO SELADOS OU COM SELOS DE IPI DE LEGITIMIDADE DUVIDOSA. DEVER DO COMERCIANTE DE VERIFICAÇÃO DA REGULARIDADE. IRRELEVÂNCIA DA ALEGAÇÃO DE BOA-FÉ. LEGALIDADE DA ATUAÇÃO FISCAL. 1 - "1. A Lei $n^{\circ} 4.502 / 64$ prevê a aplicação da pena de perdimento e apreensão de mercadoria sem selo de IPI ou com selo de legitimidade duvidosa. 2. A empresa que comercializa mercadoria sujeita ao selo do IPI tem a obrigação de verificar a correta aposição do selo, sob pena de ficar responsável pelo pagamento dos tributos e sofrer as sanções cabíveis. 3. Em se tratando de infração à legislação tributária, não há que se aferir a real intenção do agente quando da prática do ato, razão pela qual carece de importância a alegação de boa-fé. 4. A fiscalização se ateve ao estrito cumprimento do seu dever, não havendo qualquer arbitrariedade no ato de apreensão, ou ofensa aos princípios da legalidade, do contraditório e da ampla defesa. 5. Apelação desprovida. (AMS 0035343-36.2003.4.01.3800/MG, Rel. JUIZ FEDERAL WILSON ALVES DE SOUZA, 5 TURMA SUPLEMENTAR, e-DJF1 p.1257 de 23/11/2012)." 2 - Remessa oficial e apelação providas, prejudicado o recurso adesivo. (AMS 0010700-73.2001.4.01.3900/PA, Rel. JUIZ FEDERAL GRIGÓRIO CARLOS DOS SANTOS, 5 TURMA SUPLEMENTAR, e-DJF1 p.1079 de 11/10/2013). 
selo ou seu uso em desacordo com as normas regulamentares implica considerar o produto como não identificado com o descrito nos documentos fiscais. Adiante, no art. 62, atribui responsabilidade para o adquirente das mercadorias de verificar a presença do selo ou da sua correta aposição. Caso as mercadorias cujos selos não estejam em conformidade com a lei, o art. 99 permite a sua apreensão, inclusive, com posterior pena de perdimento da mercadoria. Diante desses fundamentos legais, o Tribunal Federal, verificando haver indícios de infração punível com a pena de perdimento, decidiu pela validade da retenção das mercadorias até que seja concluído o processo administrativo como medida necessária para acautelar os interesses do órgão fazendário.

Observe-se, que na situação concreta apresentada, a apreensão questionada decorre de previsão legal, destinada à aplicação da pena de perdimento da mercadoria. Desse modo, não haveria arbitrariedades no ato de fiscalização realizado pela Administração Tributária, tendo em vista que se ateve ao estrito cumprimento do seu dever, seguindo rigorosamente os ditames legais.

Entretanto, não basta uma lei determinando as diretrizes para a atividade fiscalizatória ser considerada lícita. Requer-se que a sua produção tenha seguido os dispositivos constitucionais, especialmente os direitos individuais do contribuinte. Ademais, a atividade fiscalizatória também deve respeitar os direitos fundamentais.

É sabido que a Constituição da República Federativa do Brasil possui um vasto rol de direitos e garantias individuais. Quando eles têm por finalidade garantir uma justa tributação, sem arbitrariedades, constroem um verdadeiro "estatuto do contribuinte", expressão "[...] criada por Juan Carlos Luqui em 1953 e se refere ao grupo de normas constitucionais que asseguram os direitos fundamentais do cidadão em matéria tributária" (GRUPENMACHER, 2004, p. 13).

Diante disso, uma lei que regulamente a fiscalização tributária tem de seguir o estatuto do contribuinte, não podendo se sobrepor aos direitos fundamentais da privacidade, da inviolabilidade de domicílio, da liberdade de trabalho, etc. Nesse sentido, tanto a doutrina como os tribunais superiores ${ }^{7}$ condenam as "sanções políticas", que são as exigências feitas aos contribuintes pela Administração Tributária como forma indireta de coagi-lo ao

\footnotetext{
${ }^{7}$ O STF vem, reiteradamente, declarando a ilicitude desses atos. Eis o teor de suas súmulas: Súmula 70: é inadmissível a interdição de estabelecimento como meio coercitivo para o pagamento de tributo; Súmula 323: é inadmissível a apreensão de mercadorias como meio coercitivo para o pagamento de tributos; Súmula 547: não é lícito à autoridade proibir que o contribuinte em débito adquira estampilhas, despache mercadorias nas alfândegas e exerça suas atividades profissionais.
} 
pagamento de tributos, por serem atos incompatíveis com os direitos fundamentais do contribuinte.

O sistema jurídico forneceu à Administração Tributária elementos suficientes para exercer a fiscalização e arrecadação dos tributos. Há todo um rito descrito na legislação tributária, que se inicia com o lançamento, a inscrição em dívida ativa e a execução fiscal, ação de rito específico, com vantagens para o Poder Público cobrar o crédito tributário. Não se pode valer, portanto, de outros meios de coação contra o contribuinte, para obrigá-lo a pagar os seus débitos, principalmente se afrontarem a lei e os direitos fundamentais.

Interessante mencionar a Apelação Cível $\mathrm{n}^{\mathrm{o}} 10024131986606002$, julgada pela $2^{\mathrm{a}}$ Câmara Cível do Tribunal de Justiça de Minas Gerais em 22/04/2014 ${ }^{8}$, em que se discute a legalidade da inclusão da apelada no regime especial de tributação. Em que pese exista a previsão na legislação do Estado de Minas acerca do regime especial de tributação, decidiu-se que sua aplicação, nesse caso específico, deu-se sem o necessário procedimento administrativo tributário anterior e sem constatar a prática reiterada de atos que visem burlar o recolhimento de tributos. Concluiu que o enquadramento da apelante no regime especial tributário teve o condão de coagi-la ao pagamento de tributos, caracterizando a violação dos direitos fundamentais do contribuinte, especialmente o do livre exercício da atividade, da ampla defesa e contraditório.

Os casos apresentados confirmam as ideias desenvolvidas no decorrer deste estudo. Observa-se que a atividade de fiscalização, essencial para a estrutura da Administração Tributária, mesmo que possua alguns privilégios, possui limites, especialmente no princípio da legalidade, que é um dos fundamentos do regime jurídico administrativo, e nos direitos fundamentais do contribuinte. Qualquer ato realizado pela fiscalização que não encontre

\footnotetext{
${ }^{8}$ MANDADO DE SEGURANÇA - TRIBUTÁRIO - ICMS - REGIME ESPECIAL DE CONTROLE E FISCALIZAÇÃO - PRESUNÇÃ̃O RELATIVA DE LEGALIDADE - VIOLAÇÃO AO PRINCÍPIO DA AMPLA DEFESA - PONDERAÇÃO DE VALORES - AUSÊNCIA DE PRÁTICA REITERADA - MEDIDA QUE CARACTERIZA COAÇÃO AO PAGAMENTO DE TRIBUTO - ILEGALIDADE - PRECEDENTE DO STJ - SENTENÇA CONFIRMADA EM REEXAME NECESSÁRIO. 1 - Alinhado aos atuais precedentes do STJ, somente se admite a imposição do regime especial aos contribuintes que comprovadamente sejam reincidentes na prática de infrações tributárias, como meio inerente ao poder de polícia e necessário para que a administração pública possa prevenir novos prejuízos ao erário. 2 - A aplicação de regime especial de controle e fiscalização tributário não pode ser utilizado como meio de coação para o pagamento de tributo, caracterizandose como ilegal e arbitrário. (TJMG - Ap Cível/Reex Necessário 1.0024.13.198660-6/002, Relator(a): Des.(a) Marcelo Rodrigues , $2^{\mathrm{a}}$ CÂMARA CÍVEL, julgamento em 22/04/2014, publicação da súmula em 07/05/2014).
} 
amparo legal ou que desrespeite algum direito fundamental tem de ser considerado arbitrário e ilegal.

Constata-se que em ambos os casos os Tribunais confirmam a necessidade de observância da legalidade bem como dos direitos fundamentais individuais do contribuinte nos atos de fiscalização efetuados pela Administração Tributária, seja para a aplicação da pena de perdimento de bens, seja para inclusão da empresa em Regime Especial Tributário, demonstrando que não se trata de um direito/dever absoluto da Administração Pública, haja vista ter como limite a própria lei e nos direitos e garantias fundamentais do contribuinte.

\section{CONCLUSÃO}

No contexto de um Estado de Direto atribui-se à lei o limite para impor restrições à atividade administrativa, inclusive no âmbito da fiscalização tributária. Nesse caso, a Administração Pública exerce seu poder junto "às pessoas naturais ou jurídicas, contribuintes ou não, inclusive às que gozem de imunidade tributária ou de isenção de caráter pessoal" (art. 194 do CTN) pela aplicação da legislação tributária, sendo esta quem regulará “os poderes das 
autoridades administrativas em matéria de fisscalização da sua aplicação" (parágrafo único do art. 194 do CTN).

Como demonstrado neste trabalho, a Administração Tributária, mesmo possuindo privilégios no cumprimento de seu mister, deve respeitar, além da legislação tributária propriamente dita, os direitos fundamentais individuais dos fiscalizados. Assim este limite, dúplice, encontra-se normatizado por regras e/ou princípios.

Para dar apoio pragmático à pesquisa, utilizou-se de dois casos jurisprudenciais que evidenciariam a duplicidade deste limite, demonstrando a necessidade de ponderação entre os privilégios legalmente conferidos à Administração Pública e os direitos fundamentais daqueles sobre o quais se exercem tais privilégios, havendo um posicionamento assumido pela doutrina e jurisprudência de que não basta a existência de lei determinando as diretrizes para a atividade fiscalizatória ser considerada lícita; requer-se que a sua produção tenha seguido os dispositivos constitucionais, especialmente os direitos individuais do contribuinte. Ademais, a atividade fiscalizatória também deve respeitar os direitos fundamentais já positivados.

Portanto, verifica-se que a atividade de fiscalização tributária age em torno da arrecadação do tributo, bem como do cumprimento da legislação tributária e que seu exercício também tem como base e limite a lei, bem como os direitos fundamentais do fiscalizado, Contudo, para que possa se falar em uma fiscalização tributária legal, justa e adequada deve ainda se observar que no contexto de um Estado de Direito não há que se referir em absolutismo da legislação tributária ou até mesmo dos direitos fundamentais do fiscalizado devendo a Administração Pública e o Judiciário ponderar suas aplicações a cada caso.

\section{REFERÊNCIAS}

ASSONI, Sergio Filho. O princípio da legalidade tributária. Revista da Faculdade de Direito da Universidade de São Paulo. São Paulo,v. 98, p. 181-206, 2003. Disponível em: <http://www.revistas.usp.br/rfdusp/article/viewFile/67585/70195.> Acesso em: 12 de julho de 2016.

BARRETO, Aires. Base de cálculo, alíquota e princípios constitucionais. São Paulo: Max Limonad, 1998. 
BESTER, Gisela Maria. Direito Constitucional: fundamentos teóricos. São Paulo: Manole, 2005. v. 01.

BRASIL. Código Tributário Nacional. Disponível em: <http://www.planalto.gov.br/ccivil_03/leis/L5172Compilado.htm.> Acesso em: 16 de julho de 2016.

Constituição (1988). Constituição da República Federativa do Brasil. Disponível em: <\&lt;http://www.planalto.gov.br/ccivil_03/constituicao/constitui \%C3\%A7ao.htm\&gt;>. Acesso em: 10 de julho de 2015.

BRITO, Jaime Domingues; RUIZ, Fernando Teixeira. A servidão administrativa e o princípio da legalidade na constituição de 1988. Argumenta Journal Law, Jacarezinho - PR, n. 3, p. 225-241, jan. 2013. Disponível em: $<$ http://seer.uenp.edu.br/index.php/argumenta/article/view/24/25>. Acesso em: 28 julho de 2016.

CARRAZZA, Roque Antonio. Curso de direito constitucional tributário. 16. ed. rev. ampl. e atual. São Paulo: Malheiros, 2001.

COMPARATO, Fabio Konder. A afirmação histórica dos Direitos Humanos. 8. ed. São Paulo: Saraiva, 2013.

CUNHA JUNIOR, Dirley da. Curso de Direito Constitucional. 2. ed. Bahia: Juspodivm, 2008 .

DALLARI, Dalmo de Abreu. Elementos de teoria geral do Estado. 28 ed. São Paulo: Saraiva, 2009.

DI PIETRO, Maria Sylvia Zanella. Direito administrativo. 28. ed., São Paulo: Atlas, 2015.

FALCÃO, Amilcar de Araújo. Fato gerador da obrigação tributária. 7. ed. São Paulo: Noeses, 2013.

FREITAS, Juarez. O controle dos atos administrativos e os princípios fundamentais. 4. ed. São Paulo: Malheiros, 2009.

GRUPENMACHER, Betina Treiger. Tributação e direitos fundamentais. In: FISCHER, Octavio Campos (coord.). Tributos e direitos fundamentais. São Paulo: Dialética, 2004. p. 09-17.

HOSPERS, Jhon. Introducción al análisis filosófico. 2. ed. Madrid: Alianza Universidad Textos, 1984.

LAPATZA, José Juan Ferreiro. Direito tributário: teoria geral do tributo. Barueri: Manole; Espanha: Marcial Pons, 2007. 
MELLO, Celso Antonio Bandeira de. Curso de direito administrativo. 31. ed. rev. e atual. São Paulo: Malheiros, 2014.

MENDES, Gilmar Ferreira; BRANCO, Paulo Gustavo Gonet. Curso de Direito Constitucional. 9. ed. rev. e atual. São Paulo: Saraiva, 2014.

NOGUEIRA, Ruy Barbosa. Curso de direito tributário. 14. ed. atual. São Paulo: Saraiva, 1995.

SILVA, José Afonso da. Curso de direito constitucional positivo. 15. ed. rev. São Paulo: Malheiros, 1998.

UCKMAR, Victor. Princípios comuns de direito constitucional tributário. São Paulo: Revista dos Tribunais, 1976.

VIEIRA, José Roberto. Legalidade tributária e medida provisória: mel e veneno. In: FISCHER, Octavio Campos (coord.). Tributos e direitos fundamentais. São Paulo: Dialética, 2004. p. 175-216.

XAVIER, Alberto. Os princípios da legalidade e da tipicidade da tributação. São Paulo: Revista dos Tribunais, 1978. 